\title{
Microbial consortium and pig slurry to improve chemical properties of degraded soil and nutrient plant uptake (Schoebitz and Vidal, 2016)
}

\author{
M. Schoebitz ${ }^{1 *}$ and G. Vidal ${ }^{2}$ \\ ${ }^{1}$ Departamento de Suelos y Recursos Naturales. Facultad de Agronomía, Campus Concepción, Casilla 160-C. \\ Universidad de Concepción, Concepción, Chile. ${ }^{2}$ Grupo de Ingeniería y Biotecnología Ambiental. Facultad de \\ Ciencias Ambientales y Centro EULA-Chile, Universidad de Concepción, Concepción, Chile. *Corresponding \\ author:mschoebitz@udec.cl
}

\begin{abstract}
A greenhouse experiment was carried out to assess the effectiveness of commercial microbial consortium (MC) and the addition of pig slurry (PS) on the growth of L. perenne and the enhancement of soil properties. The combined treatment of microbial consortium and pig slurry (MC+PS) was the most effective in terms of root dry weight compared to the control plants, reaching a 14-fold and 4-fold increase in Quillón and Florida soils, respectively, while the pig slurry and the combined MC+PS treatments resulted in a 4-fold increase in shoot dry weight. Values of available nitrogen, phosphorus and potassium content in both soils were higher than the nonamended soils. Foliar levels of N, P and K increased with the use of pig slurry and MC+PS, but not with the use of microbial consortium alone. The combined treatment of microbial consortium and pig slurry also enhanced the chemical quality of the soil and nutrient uptake by L. perenne. The application of beneficial microorganisms to the soil can enhance nutrient uptake and increase the efficiency of organic amendments. In this regard, the combined use of microbial consortium and pig slurry has a potential role in the development of sustainable systems for grassland production.
\end{abstract}

Keywords: Biofertilizers, microbial inoculant, nutrient uptake, pig manure

\section{Introduction}

Plant growth and yield crop production are affected by different parameters, including soil, plant, and climate properties. Plants require nutrients for their optimal growth and production. Chemical fertilization, which is one of the methods of enhancing nutrient quantity and availability for plant utilization, is a fast way of providing plant with the necessary nutrients
(Miransari, 2011). The use of chemical fertilizers to improve soil quality and crop production can often result in leaching and runoff of nutrients, especially nitrogen $(\mathrm{N})$, phosphorus $(\mathrm{P})$ and potassium $(\mathrm{K})$, leading to environmental degradation. The low use efficiency of fertilizers and their continuous longterm use can account for this situation (Adesemoye 
and Kloepper, 2009). Different studies have been conducted in order to improve the use efficiency of fertilizers, including the use of beneficial soil microorganisms. In fact, the use of microorganisms has a potential role in developing sustainable systems for crop production (Dodd and Ruiz-Lozano, 2012). Bacteria, fungi and actinomycetes are an important part of the soil microbiota, which are known for their ability to promote biological nitrogen fixation and phosphate solubilization, increase the root surface area and improve plant growth (Shahid et al., 2012). Bacillus sp. and Enterobacter sp. may enhance plant growth by improving the supply of nutrients of low mobility in the soil, such as phosphorous. Thus, microbial inoculation may have a potential role in the establishment of plant species in degraded lands (Mengual et al., 2014).

The use of organic waste material not only increases fertility of soils, but also contributes to the palliation of environmental and economical inconveniences related to waste disposal (Mengual et al., 2014). Pig slurry is a valuable fertilizer for crop production (Antezana et al., 2016) and its application as a fertilizer is a cost-effective alternative that can enhance plant growth and reduce mineral fertilizer application (Belota et al., 2014).

Some recent studies showed the beneficial effects of the application of organic amendments in combination with inoculated bacteria, for example, olive-mill waste (Schoebitz et al., 2014) and sugar beet residue. The beneficial effects on soil physicochemical properties due to the increased proliferation and development of natural populations of soil microbiota have also been described in the literature (Mengual et al., 2014). The main objective of this study is to assess the effect of pig slurry and microbial consortium consisting of bacteria, fungi and actinomycetes on two different types of degraded soils, also evaluating the effect on ryegrass growth and nutrient uptake under greenhouse conditions. We hypothesize that the effect of the application of microbial consortium and pig slurry into the soil can effectively improve chemical soil properties and nutrient availability, principally of nitrogen, phosphorous and potassium. This change on degraded soil properties could then affect root development, foliar nutrient uptake and ryegrass performance.

\section{Materials and Methods}

\subsection{Soils}

The soils used on the experiments were obtained from agricultural fields located in the Bío Bío Region, in the central-southern zone of Chile. The main characteristics of the soils are described in Table 1 . Sandy loam soil was collected in Florida $\left(36^{\circ} 49^{\prime} 00^{\prime \prime}\right.$ $\left.\mathrm{S} ; 72^{\circ} 40^{\prime} 00^{\prime \prime} \mathrm{W}\right)$ and clay soil was collected in Quillón ( $\left.36^{\circ} 44^{\prime} 40^{\prime \prime} \mathrm{S} ; 7^{\circ} 28^{\prime} 36^{\prime \prime} \mathrm{W}\right)$. The soils were obtained up to $20 \mathrm{~cm}$ of depth and were classified as fine, kaolinitic, thermic UlticPalexeralf (Cauquenes Series), derived from granitic materials, with moderate permeability, moderate drainage and rapid run-off (Quezada et al., 2014). 
Table 1. Physico-chemical characteristics of the soils used in the experiment

\begin{tabular}{lll}
\hline & Florida & Quillón \\
\hline $\mathrm{pH}$ & 6.3 & 6.4 \\
Organic Matter $(\%)$ & 3.6 & 4.0 \\
$\mathrm{NO}_{3}\left(\mathrm{mg} \mathrm{kg}^{-1}\right)$ & 0.9 & 1.2 \\
$\mathrm{NH}_{4}\left(\mathrm{mg} \mathrm{kg}^{-1}\right)$ & 2.1 & 1.9 \\
$\mathrm{P}$ available $\left(\mathrm{mg} \mathrm{kg}^{-1}\right)$ & 3.8 & 5.7 \\
$\mathrm{~K}$ extractable $\left(\mathrm{mg} \mathrm{kg}^{-1}\right)$ & 221 & 305 \\
Sand & 60.0 & 39.1 \\
Loam & 20.3 & 19.5 \\
Clay & 19.7 & 41.4 \\
\hline
\end{tabular}

\subsection{Microbial consortium and pig slurry application}

The effect of commercial microbial consortium was evaluated in terms of plant growth and enhancement of chemical soil properties. This consortium contained soil beneficial microorganisms corresponding to bacteria, fungi and actinomycetes. The cell concentration of this consortium of microorganisms was about $10^{8} \mathrm{CFU} \mathrm{g}^{-1}$ (Table 2). A portion of $20 \mathrm{~g}$ of microbial consortium OikosBac 174 , was dissolved in $4 \mathrm{~L}$ of tap water and the inoculum was added at a rate of $200 \mathrm{~mL}$ per pot $\left(10^{6}\right.$
CFU mL $\left.\mathrm{m}^{-1}\right) 10$ days after germination. The pig slurry was collected from a pig farm, Bío-Bío Region. Pig slurry from a confinement facility located in Chillán (36³'19.61" S; 7151'49.64" W) was extracted after a primary treatment in which the solid was separated from the liquid phase. Then, it was transported in plastic drums and stored at $4{ }^{\circ} \mathrm{C}$. One week before sowing, $265 \mathrm{~mL}$ of pig slurry was added to each pot at arate of $350 \mathrm{~kg}$ total $\mathrm{N} \mathrm{ha}^{-1}$ year ${ }^{-1}$, based on international standards regarding total $\mathrm{N}$ application (Chartier et al., 2014).

Table 2. Microbial consortium characterization used in the experiment

\begin{tabular}{|c|c|}
\hline & $\begin{array}{c}\text { Cells/spores concentration } \\
\left(\mathrm{CFU} \mathrm{g}{ }^{-1}\right)\end{array}$ \\
\hline Bacillus subtilis & $2.12 \times 10^{8}$ \\
\hline Bacillus licheniformis & $4.0 \times 10^{8}$ \\
\hline Bacillus megaterium & $2.45 \times 10^{8}$ \\
\hline Bacillus polymyxa & $3.7 \times 10^{8}$ \\
\hline Bacillus macerans & $3.45 \times 10^{8}$ \\
\hline Pseudomonas fluorescens & $3.0 \times 10^{8}$ \\
\hline Pseudomonas putida & $3.55 \times 10^{8}$ \\
\hline Nocardia corallina & $5.2 \times 10^{8}$ \\
\hline Saccharomyces cervisiae & $4.75 \times 10^{8}$ \\
\hline Thrichoder maviride & $1.7 \times 10^{8}$ \\
\hline
\end{tabular}




\subsection{Analytical methods}

The pig slurry obtained was characterized for COD (Chemical Oxygen Demand) as described by APHAAWWA-WPCF (1998). Nutrients, such as total nitrogen, $\mathrm{NH}_{4}, \mathrm{NO}_{3}$ and total phosphorous, were evaluated by specific kits of NOVA-60 spectroquant. Additionally, potentiometric parameters $(\mathrm{pH}$, electric conductivity) were measured with a portable Oakton PC650 machine. The analytical characteristics of pig slurry were characterized prior to application to the soil (Table 3).

Table 3. Chemical characteristics of the pig slurry used in the experiment.

\begin{tabular}{lc}
\hline & Value \\
\hline $\mathrm{pH}$ & $8.0 \pm 0.1$ \\
Organic Matter (\%) & $47.5 \pm 1.1$ \\
$\mathrm{EC}^{1}\left(\mathrm{mS} \mathrm{cm}^{-1}\right)$ & $4.2 \pm 0.2$ \\
$\mathrm{Eh}^{2}(\mathrm{mV})$ & $-72.5 \pm 2.8$ \\
$\mathrm{COD}^{3}\left(\mathrm{~g} \mathrm{~L}^{-1}\right)$ & $9.8 \pm 0.8$ \\
$\mathrm{Total} \mathrm{N}\left(\mathrm{mg} \mathrm{L}^{-1}\right)$ & $492.7 \pm 20.5$ \\
$\mathrm{NO}_{3}\left(\mathrm{mg} \mathrm{L}^{-1}\right)$ & $0.8 \pm 0.0$ \\
$\mathrm{NH}_{4}\left(\mathrm{mg} \mathrm{L}^{-1}\right)$ & $389.0 \pm 14.2$ \\
Total P $\left(\mathrm{mg} \mathrm{L}^{-1}\right)$ & $14.8 \pm 0.4$ \\
Total solids $\left(\mathrm{g} \mathrm{L}^{-1}\right)$ & $6.7 \pm 0.1$ \\
Volatile solids $\left(\mathrm{g} \mathrm{L}^{-1}\right)$ & $4.4 \pm 0.2$ \\
\hline
\end{tabular}

$\mathrm{EC}^{1}$ : electrical conductivity; $\mathrm{Eh}^{2}$ : redox potential; $\mathrm{COD}^{3}$ : chemical oxygen demand. Means \pm standard error. Values are means of three replicates.

\subsection{Experimental design}

A complete aleatorized factorial assay was established with three factors and five-fold replication in a split plot design. The first factor was the inoculation of plants with microbial consortium; the second was the addition of pig slurry into the soil and the third was the soil type (Quillón and Florida). The experimental design was performed as follows: treatment 1, plants without the application of the microbial consortium treatment and soil without pig slurry addition (Control); treatment 2, plants inoculated with microbial consortium and soil without pig slurry addition; treatment 3 , plants without microbial consortium treatment and soil with pig slurry addition and treatment 4 , plants inoculated with microbial consortium and soil with pig slurry addition.

The treatments 5-8 were performed same as treatments 1-4, but using the Florida soil as substrate for the plants.

\subsection{Greenhouse experiment}

The air-dried soil and sludge were sieved in a $2 \mathrm{~mm}$ mesh. Pots with drainage holes were filled with $2 \mathrm{~kg}$ of soil. Annual ryegrass Lolium perenne L var. Nui was sown at a rate of $0.40 \mathrm{~g} \mathrm{pot}^{-1}$. Seeds of $L$. perenne were grown for 10 days in soils before the application of microbial consortium inoculation and pig slurry. $L$. perenne was harvested 59 days after inoculation and growth parameters were measured. Forty pots were evaluated in this experiment and soil water content in the pots was maintained at $70-80 \%$ of field capacity throughout the experiment.

\subsection{Plant and soil analyses}

Shoot and root dry weights were determined in order to evaluate the response to microbial consortium inoculation and pig slurry application. Measurements were made at $70{ }^{\circ} \mathrm{C}$ for $24 \mathrm{~h}$ and recorded before the chemical analysis. The foliar concentrations of $\mathrm{N}$, $\mathrm{P}$ and $\mathrm{K}$ were determined according to the method described by Sadzawka et al (2005). 
Soil $\mathrm{pH}$ was measured in a 1:2.5 (w/v) aqueous solution. Available nitrogen $\left(\mathrm{NO}_{3}\right.$ and $\left.\mathrm{NH}_{4}\right)$, available phosphorus (P), extractable potassium (K) and organic matter (\%) were determined according to proposed by Sadzawka et al. (2006).

\subsection{Statistical analysis}

The effects on plants and soil of the organic amendment, the microbial inoculation, and the combination of MC+PS were analyzed by a oneway ANOVA, while a post-hoc mean separation was performed by Duncan's multiple range test at $\mathrm{P} \leq 0.05$ using the SPSS software.

\section{Results}

3.1.Effects of the inoculation with microbial consortium and pig slurry on the growth of L. perenne.
Growth parameters were measured two months after sowing in the three treatments: microbial consortium (MC), pig slurry (PS) and the combined application of microbial consortium and pig slurry (MC+PS). Root dry weights were evaluated in the Quillón and Florida soils. Table 4 shows an increase in the root/shoot ratio in Quillón soils and statistically significant differences $(>0.05)$ in root dry weight inoculated with $\mathrm{MC}$, PS and MC+PS treatments (742\%, 833\% and $1440 \%$, respectively). In Florida soils, the pig slurry treatment resulted in an increase in root dry weight, reaching levels $229 \%$ higher than the control (Table 4), while the MC+PS treatment recorded values $406 \%$ higher than the control. The microbial consortium treatment in the Florida soil did not significantly affect the root biomass in L. perenne.

Table 4. Effects of inoculation with microbial consortium and addition of pig slurry on L. perenne growth parameters.

\begin{tabular}{lcccc}
\hline & Soil Type & Root $(\mathrm{g} \mathrm{dw})^{1}$ & Shoot $(\mathrm{g} \mathrm{dw})$ & Root/Shoot ratio \\
\hline Control & $\mathrm{Q}^{2}$ & $0.54 \pm 0.03 \mathrm{a}$ & $1.10 \pm 0.03 \mathrm{a}$ & 0.49 \\
& $\mathrm{~F}^{3}$ & $1.03 \pm 0.20 \mathrm{ab}$ & $0.93 \pm 0.09 \mathrm{a}$ & 1.10 \\
$\begin{array}{l}\text { Microbial } \\
\text { consortium (MC) }\end{array}$ & $\mathrm{Q}$ & $4.01 \pm 0.62 \mathrm{~d}$ & $1.33 \pm 0.08 \mathrm{a}$ & 3.02 \\
& $\mathrm{~F}$ & $2.00 \pm 0.27 \mathrm{bc}$ & $1.13 \pm 0.03 \mathrm{a}$ & 1.77 \\
Pig slurry (PS) & $\mathrm{Q}$ & $4.50 \pm 0.36 \mathrm{~d}$ & $4.58 \pm 0.31 \mathrm{bc}$ & 0.98 \\
& $\mathrm{~F}$ & $2.36 \pm 0.32 \mathrm{c}$ & $4.22 \pm 0.35 \mathrm{~b}$ & 0.56 \\
& $\mathrm{Q}$ & $7.78 \pm 0.65 \mathrm{e}$ & $5.41 \pm 0.33 \mathrm{~d}$ & 1.44 \\
MC+PS & $\mathrm{F}$ & $4.19 \pm 0.28 \mathrm{~d}$ & $5.15 \pm 0.36 \mathrm{~cd}$ & 0.81
\end{tabular}

Grams dry weight ${ }^{1}$; $Q^{2}$ : Quillón; $F^{3}$ : Florida. Means \pm standard error. Values are means of five replicates. Significant difference according to the Duncan test at $P<0.05$ levels were indicated by different letters. 
The effect of inoculation on shoot dry weight was also evaluated in both soils under study. The pig slurry treatment promoted an increase in shoot dry weight, reaching values $416 \%$ and $453 \%$ higher than those recorded in the control plants in the Quillón and Florida soils, respectively (Table 4). Similarly, the MC+PS treatment resulted in an increase in shoot dry weight, with values $491 \%$ and $553 \%$ higher than the control in the Quillón and Florida soils, respectively. Microbial consortium treatment had no significant effect on shoot biomass compared to the control plants.

\subsection{Soil chemical analyses}

A significant decrease in the rhizosphere soil $\mathrm{pH}$ was observed with the pig slurry and MC+PS treatments. The microbial consortium, pig slurry and $\mathrm{MC}+\mathrm{PS}$ did not increase the total organic matter in the soil. The pig slurry and $\mathrm{MC}+\mathrm{PS}$ treatments significantly increased the available $\mathrm{N}$ in the rhizosphere soil in both Quillón and Florida soils.
A significant increase in the available $\mathrm{P}$ in the rhizosphere soil was observed in the pig slurry and $\mathrm{MC}+\mathrm{PS}$ treatments. The available $\mathrm{P}$ content in Quillón soils mediated by the pig slurry and MC+PS treatments were about 2-fold higher with respect to the control plants. In Florida soil, the available P increased in the pig slurry treatment reaching a value that was $311 \%$ higher than the control, while the MC+PS treatment also recorded an increase that was $211 \%$ higher. Regarding the factorial analysis, both the pig slurry applications and the soil type were significant (Table 7). Extractable K content in the Quillón soil showed a statistically significant difference $(<0.05)$, with a $138 \%$ increase for the pig slurry and a $140 \%$ increase for the $\mathrm{MC}+\mathrm{PS}$ treatment. Extractable $\mathrm{K}$ in the Florida soil significantly increased in the pig slurry and MC+PS treatments (Table 5). Thus, the greatest increases in response to the application of pig slurry and soil type were observed in the soil extractable $\mathrm{K}$ content (Table 7).

Table 5. Soil physico-chemical properties in response to inoculation with microbial consortium and pig slurry addition.

\begin{tabular}{lcccccc}
\hline & $\begin{array}{c}\text { Soil } \\
\text { Type }\end{array}$ & $\mathrm{pH}\left(\mathrm{H}_{2} \mathrm{O}\right)$ & $\mathrm{OM}^{1}(\%)$ & $\begin{array}{c}\text { Available N } \\
\left(\mathrm{mg} \mathrm{kg}^{-1}\right)\end{array}$ & $\begin{array}{c}\text { Available P } \\
\left(\mathrm{mg} \mathrm{kg}^{-1}\right)\end{array}$ & $\begin{array}{c}\text { Extractable K } \\
\left(\mathrm{mg} \mathrm{kg}^{-1}\right)\end{array}$ \\
\hline Control & $\mathrm{Q}^{2}$ & $6.20 \pm 0.01 \mathrm{~b}$ & $2.93 \pm 0.04 \mathrm{bc}$ & $11.16 \pm 0.8 \mathrm{a}$ & $8.68 \pm 0.21 \mathrm{~b}$ & $259 \pm 14 \mathrm{bc}$ \\
& $\mathrm{F}^{3}$ & $6.11 \pm 0.01 \mathrm{~b}$ & $2.45 \pm 0.06 \mathrm{a}$ & $10.30 \pm 0.42 \mathrm{a}$ & $3.66 \pm 0.23 \mathrm{a}$ & $161 \pm 11 \mathrm{a}$ \\
$\begin{array}{l}\text { Microbial } \\
\text { consortium }\end{array}$ & $\mathrm{Q}$ & $6.34 \pm 0.03 \mathrm{~b}$ & $2.99 \pm 0.05 \mathrm{bc}$ & $9.0 \pm 0.92 \mathrm{a}$ & $9.62 \pm 0.33 \mathrm{bc}$ & $287 \pm 7 \mathrm{c}$ \\
$\begin{array}{l}\text { MC) } \\
\text { Pig slurry (PS) }\end{array}$ & $\mathrm{F}$ & $6.14 \pm 0.01 \mathrm{~b}$ & $2.46 \pm 0.07 \mathrm{a}$ & $9.42 \pm 0.71 \mathrm{a}$ & $4.20 \pm 0.38 \mathrm{a}$ & $152 \pm 3 \mathrm{a}$ \\
& $\mathrm{Q}$ & $5.57 \pm 0.12 \mathrm{a}$ & $3.07 \pm 0.07 \mathrm{c}$ & $56.60 \pm 7.62 \mathrm{~b}$ & $19.44 \pm 1.80 \mathrm{~d}$ & $360 \pm 15 \mathrm{~d}$ \\
& $\mathrm{~F}$ & $5.67 \pm 0.19 \mathrm{a}$ & $2.61 \pm 0.05 \mathrm{a}$ & $45.08 \pm 2.43 \mathrm{~b}$ & $11.40 \pm 0.66 \mathrm{c}$ & $240 \pm 15 \mathrm{~b}$ \\
& $\mathrm{Q}$ & $5.46 \pm 0.07 \mathrm{a}$ & $2.84 \pm 0.10 \mathrm{~b}$ & $76.96 \pm 3.98 \mathrm{c}$ & $18.22 \pm 0.89 \mathrm{~d}$ & $365 \pm 10 \mathrm{~d}$ \\
& & & & & & \\
& $\mathrm{~F}+\mathrm{PS}$ & $5.46 \pm 0.2 \mathrm{a}$ & $2.62 \pm 0.06 \mathrm{a}$ & $56.38 \pm 8.46 \mathrm{~b}$ & $7.74 \pm 0.20 \mathrm{~b}$ & $233 \pm 15 \mathrm{~b}$ \\
\hline
\end{tabular}

$\mathrm{OM}^{1}$ : organic matter; $\mathrm{Q}^{2}$ : Quillón; $\mathrm{F}^{3}$ : Florida. Means \pm standard error. Values are means of five replicates. Significant difference according to the Duncan test at $P<0.05$ levels were indicated by different letters 
Table 7. ANOVA for microbial consortium (MC) and pig slurry amendment (PS) and their interaction (MC+PS) on plant biomass, nutrient uptake and chemical soil properties of Quillón soil and Florida soil, given as F values (significance level).

\begin{tabular}{|c|c|c|c|c|c|c|c|}
\hline Parameter & $\begin{array}{c}\text { Microbial } \\
\text { consortium (MC) }\end{array}$ & Pig slurry (PS) & Soil (S) & $\begin{array}{l}\text { Interaction } \\
(\text { MC+PS) }\end{array}$ & $\begin{array}{l}\text { Interaction } \\
(\mathbf{M C}+\mathbf{S})\end{array}$ & $\begin{array}{l}\text { Interaction } \\
(\mathrm{PS}+\mathrm{S})\end{array}$ & $\begin{array}{l}\text { Interaction } \\
(\mathrm{MC}+\mathrm{PS}+\mathrm{S})\end{array}$ \\
\hline Root biomass & $73.86(<0.001)$ & $102.50(<0.001)$ & $42.53(<0.001)$ & $0.36(0.552)$ & $12.64(<0.001)$ & $14.36(0.01)$ & $0.896(0.351)$ \\
\hline Shoot biomass & $10.21(0.003)$ & $471.11(<0.001)$ & $2.08(0.158)$ & $3.76(0.061)$ & $0.01(0.919)$ & $0.13(0.718)$ & $0.036(0.851)$ \\
\hline $\mathrm{pH}$ & $0.337(0.565)$ & $74.11(<0.001)$ & $0.468(0.499)$ & $2.32(0.138)$ & $0.353(0.557)$ & $1.73(0.197)$ & $0.001(0.969)$ \\
\hline OM & $0.59(0.447$ & $2.97(0.094)$ & $83.24(<0.001)$ & $3.051(0.090)$ & $0.891(0.352)$ & $2.091(0.098)$ & $2.63(0.116)$ \\
\hline $\mathrm{N}$ available & $5.33(0.028)$ & $247.98(<0.001)$ & $6.89(0.013)$ & $7.84(0.009)$ & $0.39(0.535)$ & $6.52(0.016)$ & $0.696(0.410)$ \\
\hline P available & $2.04(0.162)$ & $35.30(<0.001)$ & $15.54(<0.001)$ & $3.69(0.063)$ & $1.75(0.194)$ & $0.226(0.638)$ & $1.42(0.242)$ \\
\hline $\mathrm{K}$ extractable & $0.187(0.669)$ & $102.31(<0.001)$ & $214.36(<0.001)$ & $0.29(0.594)$ & $1.77(0.192)$ & $0.241(0.627)$ & $0.419(0.522)$ \\
\hline $\mathrm{N}$ foliar & $0.74(0.395)$ & $305.27(<0.001)$ & $2.25(0.143)$ & $0.425(0.519)$ & $0.65(0.425)$ & $0.29(0.591)$ & $0.499(0.485)$ \\
\hline $\mathrm{P}$ foliar & $0.01(0.976)$ & $18.18(<0.001)$ & $7.68(0.009)$ & $0.78(0.384)$ & $0.627(0.434)$ & $6.70(0.014)$ & $1.203(0.281)$ \\
\hline $\mathrm{K}$ foliar & $0.22(0.635)$ & $15.30(<0.001)$ & $50.87(<0,001)$ & $0.48(0.49)$ & $0.30(0.586)$ & $46.99(<0.001)$ & $0.169(0.684)$ \\
\hline
\end{tabular}

\subsection{Nutrients plant uptake}

Microbial consortium treatments showed no significant effects on the shoot N, P and K content (Table 6). However, total $\mathrm{N}$ concentration in the plants in the Quillón soil had a significant increase with the addition of pig slurry (an 11-fold increase with respect to the control) and the MC+PS treatment (a 13-fold increase). In the Florida soil, $\mathrm{N}$ plant uptake showed a significant increase with the use of pig slurry and MC+PS, reaching values that were 11 and 15 -fold higher than the control, respectively. The total $\mathrm{P}$ content increased in both soils in the pig slurry and MC+PS treatments. The total $\mathrm{K}$ concentration in shoot sincreased significantly in the pig slurry and MC+PS treatments (a 3-fold increase with respect to the control) in the Quillón soil. Similarly, a significant increase was observed with the pig slurry treatment in the Florida soil, reaching a 9 and 11-fold increase respect to the control plants. The pig slurry treatment presented a significant increase in $\mathrm{N}, \mathrm{P}$ and K plant uptake (Table 7).

Table 6. Nutrients uptake on L. perenne in response to microbial consortium and addition of pig slurry according to the Duncan test at $P<0.05$ levels were indicated by different letters.

\begin{tabular}{|c|c|c|c|c|}
\hline & Soil Type & $\mathrm{N}\left(\mathrm{mg}\right.$ g plant $\left.{ }^{-1}\right)$ & $\mathrm{P}\left(\mathrm{mg}\right.$ g plant $\left.{ }^{-1}\right)$ & $\mathrm{K}\left(\mathrm{mg} g\right.$ plant $\left.{ }^{-1}\right)$ \\
\hline \multirow[t]{2}{*}{ Control } & $\mathrm{Q}^{1}$ & $14.6 \pm 0.8 \mathrm{a}$ & $4.48 \pm 0.21 \mathrm{a}$ & $26.0 \pm 4.6 \mathrm{a}$ \\
\hline & $\mathrm{F}^{2}$ & $13.1 \pm 0.9 \mathrm{a}$ & $2.67 \pm 0.34 \mathrm{a}$ & $25.1 \pm 7.9 \mathrm{a}$ \\
\hline \multirow{2}{*}{$\begin{array}{l}\text { Microbial } \\
\text { consortium (MC) }\end{array}$} & Q & $18.0 \pm 1.9 \mathrm{a}$ & $6.52 \pm 1.57 \mathrm{ab}$ & $40.0 \pm 8.3 \mathrm{a}$ \\
\hline & $\mathrm{F}$ & $16.7 \pm 1.1 \mathrm{a}$ & $2.84 \pm 0.16 \mathrm{a}$ & $31.4 \pm 5.8 \mathrm{a}$ \\
\hline \multirow[t]{2}{*}{ Pig slurry (PS) } & Q & $160.4 \pm 10.9 \mathrm{bc}$ & $11.16 \pm 1.48 \mathrm{c}$ & $83.4 \pm 6.4 b$ \\
\hline & $\mathrm{F}$ & $150.8 \pm 17.7 \mathrm{~b}$ & $9.53 \pm 1.52 \mathrm{bc}$ & $247.1 \pm 30.1 \mathrm{c}$ \\
\hline \multirow[t]{2}{*}{$\mathrm{MC}+\mathrm{PS}$} & Q & $189.7 \pm 12.9 \mathrm{~cd}$ & $10.79 \pm 1.15 \mathrm{c}$ & $97.1 \pm 5.7 \mathrm{~b}$ \\
\hline & $\mathrm{F}$ & $204.6 \pm 23.5 \mathrm{~d}$ & $10.49 \pm 2.02 \mathrm{c}$ & $293.6 \pm 23.5 \mathrm{~d}$ \\
\hline
\end{tabular}

$\mathrm{Q}^{1}$ : Quillón; F²: Florida. Means \pm standard error. Values are means of five replicates. Significant difference according to the Duncan test at $\mathrm{P}<0.05$ levels were indicated by different letters. 


\section{Discussion}

Under the assayed conditions, the combined pig slurry and microbial consortium inoculation in two degraded soils increased the plant performance of L. perenne. A period of two months was considered enough to ascertain the effects of combined application of microbial consortium and pig slurry on plant performance and soil properties. Plants showed different levels of response to the microbial inoculant and the addition of the organic residue. Thus, an increase in shoot biomass was observed in both soils with the pig slurry and MC+PS treatments. It has been suggested that the use of microbial consortium could be a biotechnological tool for plant growth promotion (Khan et al., 2009; Thilagar et al., 2016). It is well documented that soil microorganisms exert a beneficial effect on plant growth and many different microorganisms have been commercialized to be used in agriculture (Bashan et al. 2014). Besides, the development of a plant-growth-promoting consortium could be a feasible strategy for increased activity and better viability of plant-growth-promoting rhizobacteria and fungi (Singh et al., 2010; Chauhan and Bagyaraj 2015). When these strains are made into an inocula consortium, each of the constituent strains of the consortium not only competes with the others for rhizospheric establishment, but it is also functionally complementary for plant growth promotion. Depending on the strain combination, microbial interactions within these consortia have positive or negative effects on inoculant establishment on roots and may result or not in enhanced plant growth in comparison with single inoculations (Couillerot et al., 2013). According to Jhaand Saraf, root and shoot biomass were maximized with microbial consortium compared to the untreated control and individual trials of microorganisms. A study conducted by Walker et al. (2012) showed that the inoculation of Azospirillum sp. Pseudomonas sp. and Glomus sp. consortia under low-fertilizer input conditions resulted in enhanced root system development when compared to the noninoculated control. This is a well-known strategy that enables organisms to successfully survive and maintain themselves in communities. Previous microbial studies performed without plants have indicated that some combinations allow the bacteria to interact with each other synergistically, provide nutrients and stimulate each other through physical and biochemical activities that may enhance some beneficial aspects of their physiology Jhaand Saraf, Assuming that root/shoot ratio could reflect the degree of microorganisms effectiveness (Schoebitz et al., 2014), L. perenne respond to inoculation with microbial consortium alone in both soils under study, reaching the most significant increases in root/ shoot ratio. The pig slurry and $\mathrm{MC}+\mathrm{PS}$ treatments showed a positive response in the Quillón soil. The decreased root/shoot ratio in the pig slurry and $\mathrm{MC}+\mathrm{PS}$ treatments in the Florida soil indicates low microorganism activity in relation to root biomass production.

Total $\mathrm{N}$ levels in the soil increased with the application of pig slurry and MC+PS. A decrease was even observed in the microbial consortium treatment, which may be explained by the $\mathrm{N}$ assimilation by the soil microorganisms. With respect to the treatments that included pig slurry, it is assumed that the addition of the amendment mediates $\mathrm{N}$ levels, principally $\mathrm{NH}_{4}$, which may be attributable to the input of $\mathrm{N}$ provided by the pig slurry.

Pig slurry and $\mathrm{MC}+\mathrm{PS}$ increased the total $\mathrm{N}$ level in the rhizosphere soil. The highest value was observed with the MC+PS treatment in the Quillón soil. It can be assumed that the addition of this amendment would mediate an input of $\mathrm{N}$ and that beneficial bacteria, fungi and actinomycetes inoculated into the soil were able to fix $\mathrm{N}_{2}$. The application of amendments and 
microorganisms has been used to increase nutrient availability in the soil and improve plant growth and nutrient uptake (Schoebitz et al., 2014). However, we observed a significant increase on $\mathrm{N}$ soil content when the MC+PS treatment was applied in the Quillón soil, suggesting than the high clay level (41.4\%) adsorbed more amount of $\mathrm{NH}_{4}+$ than the Florida soil (19.7\%). This may be attributable to the fact that clay particles generally have a negative (-) charge, so they attract and hold positively $(+)$ charged nutrients and no-nutrients. However, soil organic matter has negative charge so it can hold cations, but no significant differences were found in the soils under study in terms of organic matter content after 59 days of experiment.

In our experiment, available $\mathrm{P}$ in the rhizosphere soil increased with the use of the pig slurry and the $\mathrm{MC}+\mathrm{PS}$ treatments, which leads to assume that the inoculated microorganisms were able to solubilize $\mathrm{P}$ from both the soil and the applied organic residue. In fact, soil microflora is able to excrete organic acids and/or enzymes involved in the P cycle, which increases the concentration of $\mathrm{P}$ in rhizosphere soil (Vassilev et al., 2006).

Both the pig slurry and the MC+PS treatments increased the extractable $\mathrm{K}$ content in the rhizosphere soil with respect to the control, due to the mobilization of $\mathrm{K}$ by soil microorganisms. Since the microbial inoculant treatments helped plants to compensate for deficiencies of immobile nutrients, the application of $\mathrm{MC}+\mathrm{PS}$ with microorganisms can be considered as an effective tool for the development of biofertilizers that could partially substitute chemical fertilization. In this regard, the introduction of a microbial inoculant can improve nutrient availability to plants and thereby increase the efficiency of applied manures (Adesemoye and Kloepper, 2009). However, no significant increase was observed in terms of organic matter in any of the soils under study, which suggests that the introduced microbiota presented a lower biological activity to degrade pig slurry in two months. Besides, the input of organic matter to soil through pig slurry is relatively low compared to other manure categories due to the relatively small content of organic carbon and the labile nature of the organic compounds (Antezana et al., 2016; Fangueiro et al., 2012).

Our results are in agreement with those found by other authors, who reported that the use of organic amendments had a pronounced beneficial effect on nutrients uptake conditions (Belota et al., 2014; Mengual et al., 2014). In our experiment with $L$. perenne, pig slurry and MC+PS increased the total $\mathrm{N}, \mathrm{P}$ and $\mathrm{K}$ content in shoots. Higher P and $\mathrm{K}$ uptake may be attributable to the increase on root biomass and the mobilization of nutrients from soil because of the secretion of organic acids mediated by soil microorganisms (Basak and Biswas 2010) and also to the addition of the pig slurry due to the N, P and $\mathrm{K}$ amounts incorporated with the amendment. Similar results were reported by Caravaca et al. (2003), who conducted an experiment adding organic amendment to soil and reported an increase of plant nutrient content (NPK) after the organic residue addition.

\section{Conclusions}

The microbial inoculation and pig slurry application of the L. perenne increased the performance of plants, even more when the microbial inoculation and pig slurry were applied separately. When considering the improvement of nutrients, the treatments that included pig slurry were the most effective and resulted in a significant increase in $\mathrm{N}$ available, $\mathrm{P}$ available, $\mathrm{K}$ extractable in both soils, while nutrient uptake by plants also increased. However, microbial consortium applied alone failed to increase soil chemical properties and nutrient uptake. Therefore, the application of the MC+PS treatment seems to be 
the most suitable tool to aid in the performance of $L$. perenne and soil quality in degraded soils.

\section{Acknowledgements}

This research was supported by CONICYT/ FONDAP/15130015.

\section{References}

Adesemoye, A.O., Kloepper, J.W. 2009. Plantmicrobes interactions in enhanced fertilizer-use efficiency. Appl. Microbiol. Biotechnol. 85(1), 1-12.

American Public Health Association (APHA), American Water Works Association (AWWA), Pollution Control Federation (WPCF) 1998. Standard Methods for examination of water and wastewater 16th ed. Washington.

Antezana, W., De Blas, C., Garcia-Rebollar, P., Rodriguez, C., Beccaccia, A., Ferrer, P., Cerisuelo, A., Moset, V., Estelles, F., Cambra-Lopez, M., Calvet, S. 2016. Composition, potential emissions and agricultural value of pig slurry from Spanish commercial farms. Nutr. Cycl. Agroecosyst. DOI 10.1007/s10705-016-9764-3.

Basak, B.B., Biswas, D.R. 2010. Co-inoculation of potassium solubilizing and nitrogen fixing bacteria on solubilization of waste mica and their effect on growth promotion and nutrient acquisition by a forage crop. Biol. Fertil. Soils. 46, 641-648.

Bashan, Y., de-Bashan, L.E., Prabhu, S.R., Hernandez, J.P. 2014. Advances in plant growth-promoting bacterial inoculant technology: formulations and practical perspectives (1998-2013). Plant Soil. 378, 1-33.
Belota, E., Machineski, O., Hamid, K., Yada, I., Barbosa, G., Nakatani, A., Coyne, M. 2014. Soil microbial properties after long-term swine slurry application to conventional and no-tillage systems in Brazil. Sci. Total Environ. 490, 397-404.

Caravaca, F., Figueroa, D., Alguacil, M.M., Roldán, A. 2003. Application of composted urban residue enhanced the performance of afforested shrub species in a degraded semiarid land. Bioresour. Technol. 90, 65-70.

Chartier, C., Lopez, D., Vidal, G. 2014. Anaerobic Technology Influence on Pig Slurry Biofertirrigation: Evaluation of Enteric Bacteria. Water Air and Soil Pollution. 225(1), 1780-1790.

Chauhan, H., Bagyaraj, D.J. 2015. Inoculation with selected microbial consortia not only enhances growth and yield of French bean but also reduces fertilizer application under field condition. Sci. Hort. 197, 441-446.

Couillerot, O., Ramirez-Trujillo, A., Walker, V., von Felten, A., Jansa, J., Maurhofer, M., Defago, G., Prigent-Combaret, C., Comte, G., Caballero-Mellado, J., Moenne-Loccoz, Y. 2013. Comparison of prominent Azospirillum strains in Azospirillum-Pseudomonas-Glomus consortia for promotion of maize growth. Appl. Microbiol. Biotechnol. 97, 4639-49.

Dodd, I.C., Ruiz-Lozano, J.M. 2012. Microbial enhancement of crop resource use efficiency. Curr.Opin. Biotechnol. 23, 236-242.

Fangueiro, D., Ribeiro, H., Vasconcelos, E., Coutinho, J., Cabral, F. 2012. Influence of animal slurries composition and relative particle size fractions on the $\mathrm{C}$ and $\mathrm{N}$ mineralization following soil incorporation. Biomass Bioenergy. 47, 50-51.

Jha, C.K., Saraf, M. 2012.Evaluation of multispecies plant-growth promoting consortia for the growth promotion of Jatropha curcas L. J. Plant Growth Regul. 31, 588-598. 
Khan, M.A., Khokhar, S.N., Ahmed, R., Afzal, A. 2009. Wheat growth and yield in response to coinoculation of Rhizobium, Azospirillum and Pseudomonas under rainfed conditions. Int. J. Biol. Biotechnol. 6, 257-263.

Mengual, C., Schoebitz, M., Azcon, R., Roldan, A. 2014. Microbial inoculants and organic amendment improves plant establishment and soil rehabilitation under semiarid conditions. J. Environ. Manage. 134, 1-7.

Miransari, M. 2011. Soil microbes and plant fertilization. Appl. Microbiol. Biotechnol. 92(5), 875-885.

Quezada, C., Soriano, M.A., Diaz, J., Merino, R., Chandia, A., Campos, J., M. Sandoval. 2014. Influence of soil physical properties on grapevine yiled and maturity components in an ultic palexeralf soils, central-southern Chile. Open Journal of soil science. 4, 127-135.

Sadzawka, A., Carrasco, M., Grez, R., Mora, M. 2005. Métodos de análisis de compost. SerieActas No 30.142 p. Instituto de Investigaciones Agropecuarias, Centro Regional de Investigación La Platina, Santiago, Chile.

Sadzawka, A., Carrasco, M., Grez, R., Mora, M., Flores, H., Neaman, A. 2006. Métodos de análisis recomendados para los suelos de Chile. Serie Actas No 30. 164 p. Instituto de Investigaciones Agropecuarias, Centro Regional de Investigación La Platina, Santiago, Chile.

Schoebitz, M., Mengual, C., Roldan, A. 2014. Combined effects of clay immobilized Azospirillum brasilense and Pantoea dispersa and organic olive residue on plant performance and soil properties in the revegetation of a semiarid area. Sci. Total Environ. 466-467, 67-73.
Shahid, M., Hameed, S., Imran, A., Ali, S., van Elsas, J.D. 2012. Root colonization and growth promotion of sunflower (Helianthus annuus L.) by phosphate solubilizing Enterobacter sp. Fs11. World J. Microbiol. Biotechnol. 28(8), 27492758.

Singh, S.R., Zargar, M.Y., Singh, U., Ishaq, M. 2010. Influence of bio-inoculants and inorganic fertilizers on yield, nutrient balance, microbial dynamics and quality of strawberry (Fragariaxananassa) under rain fed conditions of Kashmir valley. Indian J. Agric. Sci. 80, 275-281.

Thilagar, G., Bagyaraj, D.J., Rao, M.S. 2016. Selected microbial consortia developed for chilly reduces application of chemical fertilizers by $50 \%$ under field conditions. Sci. hort. 198, 27-35.

Vassilev, N., Vassileva, M., Nikolaeva, I. 2006. Simultaneous P-solubilizing and biocontrol activity of microorganisms: potentials and future trends. Appl. Microbiol. Biotechnol. 71, 137-44

Walker, V., Couillerot, O., Von Felten, A., Bellvert, F., Jansa, J., Maurhofer, M., Bally, R., MoenneLoccoz, Y., Comte, G. 2012. Variation of secondary metabolite levels in maize seedling roots induced by inoculation with Azospirillum, Pseudomonas and Glomus consortium under field conditions. Plant and Soil. 356, 151-163. 